ORIGINAL ARTICLE

\section{Analysis of the affinity of the principles of corporate governance to the ISO 14001 environmental management system standard}

\author{
Análise da afinidade dos princípios da governança corporativa à \\ norma de sistema de gestão ambiental ISO 14001
}

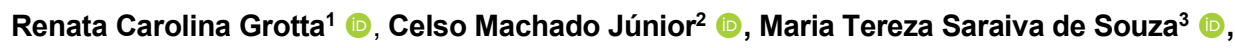 \\ Daielly Melina Nassif Mantovani Ribeiro ${ }^{4} \mathbb{C}$, Roberto Bazanini ${ }^{5}$ []
}

How to cite: Grotta, R. C., Machado Júnior, C., Souza, M. T. S., Ribeiro, D. M. N. M., \& Bazanini, R. (2020). Analysis of the affinity of the principles of corporate governance to the ISO 14001 environmental management system standard. Gestão \& Produção, 27(2), e4026 https://doi.org/10.1590/0104$530 \times 4026-20$

\begin{abstract}
The purpose of this research is to analyze the adherence of the NBR ISO 14001 standard to the Brazilian Institute of Corporate Governance Code of Best Corporate Governance Practices. The perspective established in the research interprets the existence of synergy between management supported by the Environmental Management Systems standard and the Code of Best Corporate Governance Practices. The research analyzed the contents of 177 environmental audit reports, performed by a certification company, which involved a set of 139 companies certified by NBR ISO 14001. It then related the requirements of the environmental management system with the elements present in the IBGC code. It identified the adherence to several requirements in common between the two systems analyzed, thus indicating the adequacy of establishing synergy in actions, and in the information held by both, providing benefits to the organization. Environmental auditing data indicate that companies have more difficult-to-handle items related to operational control, emergency preparedness and assessment of compliance with legal and other requirements. This is important information in the context of corporate governance, since it indicates potential risks that must be eliminated in order to guarantee the perenniality of the organization.
\end{abstract}

Keywords: Sustainability; Code of best corporate governance practices; ISO 14001; Compliance.

Received May 25, 2017- Accepted Nov 8, 2017

Financial support: None. 
Resumo: O proposito desta pesquisa é de analisar a aderência da norma NBR ISO 14001 ao código das melhores práticas de governança corporativa do IBGC. A perspectiva estabelecida na investigação interpreta a existência de sinergia entre a gestão apoiada na norma de Sistemas de Gestão Ambiental e o Código de melhores práticas de Governança Corporativa. A pesquisa analisou o conteúdo de 177 relatórios de auditorias ambientais, realizados por uma empresa de certificação, que envolvem um conjunto de 139 empresas certificadas pela norma NBR ISO 14001. Na sequência, se relacionou os requisitos do sistema de gestão ambiental com os elementos presentes no código das melhores práticas do Instituto Brasileiro de Governança Corporativa IBGC. Identificou-se a aderência de vários requisitos em comum entre os dois sistemas analisados, indicando assim a adequação de se estabelecer sinergia de ações, e de informações entre ambos, estabelecendo benefícios a organização. Os dados das auditorias ambientais indicam que as empresas apresentam maior dificuldade em atender itens relacionados ao controle operacional, a preparação ao atendimento a emergências, e avaliação de atendimento aos requisitos legais e outros. informações importantes no contexto da governança corporativa, por indicar potenciais riscos que devem ser eliminados, a fim de garantir a perenidade da organização.

Palavras-chave: Sustentabilidade; Código das melhores práticas de governança corporativa; NBR ISO 14001; Compliance.

\section{Introduction}

At the end of the 20th century and the beginning of the $21 \mathrm{st}$, issues related to corporate sustainability increased in importance, establishing a scenario in which a significant number of organizations became more concerned about correct environmental performance. The involvement of society in general, as well as of stakeholders, in the organizational context demands greater management responsibility for environmental issues, as well as greater levels of transparency of information. According to Arimura et al. (2016), given the increased awareness of society, the environment has started to play a fundamental role in global competition, based on the concept of organizational transparency.

Barbieri (2011) points out that society, government and the market put pressure on organizations to become more involved with environmental issues. Therefore, managers and entrepreneurs should consider environmental issues in their decisions so that they expand their capacity to support the planet. Thus, the function of the organization in society must additionally add to the preservation of natural resources, the promotion of workers' rights and the protection of consumer interests (Morgan et al., 2009).

Aligned with the demands of society for sustainable companies, the Brazilian Institute of Corporate Governance (IBGC), a Brazilian non-profit foundation, proposes the Code of Best Corporate Governance Practices. The principles and codes of best practices in corporate governance (CG) originate from the need to introduce good practices for the economic and sustainable development of organizations. According to Muritiba and Muritiba (2015), the establishment of principles, codes and laws in CG was due to the need to provide practices that help organizations to achieve economic and sustainable growth, as well as to protect companies against fraud and wrong decisions.

Governance codes can be used as management tools for CG good practices, because, in general, they improve organizational performance and, consequently, conditions in the countries that have adopted them (Aguilera \& Cuervo-Cazurra, 2009). Thus, CG allows maximization of the value of the organization, with broader 
access to capital, improving its performance and the sustainability of its business (CVM, 2012; Black et al., 2015; IBGC, 2015).

The option for the NBR ISO 14001 standard as the implementation of this management system can be a useful tool for organizations in order to achieve their environmental objectives, with benefits to society and protection of the environment. According to Machado et al. (2013), NBR ISO 14001-certified companies show greater responsibility for environmental management, through controls, actions and structured planning for the resources employed. The management of NBR ISO 14001-certified companies provides a differential in the market, resulting in environmental benefits for the whole society.

According to NBR ISO 14001 (ABNT, 2004), evidence of successful implementation of this standard can assure stakeholders that the organization has an appropriate environmental management system in place.

In this way, the application of the ISO 14001 standard results in the improvement of the organization's relations with the environment, with benefits to society and the transparency of information. This condition potentially fulfills the demands of disclosure, accountability, compliance and corporate responsibility present in CG good practices.

Thus, this work aims to analyze the adherence of the NBR ISO 14001 standard to the IBGC's Code of Best Corporate Governance Practices. The development of this research objective has the potential to express whether the standard, besides being used by organizations as a tool to define their environmental aspects, provides elements for the management of sustainability issues in CG. In addition, when evaluating a sample of certified companies, it is possible to identify the main obstacles to their full implementation of environmental requirements, which may help in the creation of public policies to facilitate the process. To meet the proposed objective beyond this introduction, this study presents the theoretical framework, the methodological procedures, and the analysis and discussion of the data, and ends with final considerations.

\section{Theoretical framework}

IBGC (2015) defines CG as the way in which organizations are managed and monitored, involving the relationship of agents - owners, board of directors, control body and other interested parties - with the purpose of preserving and optimizing the economic value of the organization, aiming at its longevity.

Many CG theories have been developed, using terminologies based on different perspectives, in order to clarify and analyze this theme. The balance theory of stakeholder interests, originating from the areas of sociology, organizational behavior and conflict management, establishes that decisions in the organization are taken in order to balance and satisfy the interests of all the publics involved with it (Abdallah \& Ismail, 2017).

Stakeholder theory seeks to know and observe the characteristics of all those involved, establishing a good relationship between stakeholders and developing objectives compatible with them, thus allowing greater cooperation between parties. Stakeholder theory goes beyond the simple, descriptive observation that the organization has stakeholders (Harrison \& Wicks, 2013).

Thus, the purpose of governance goes beyond the control of business operations, because it provides a general guideline for the organization, with controls and 
monitoring of managers' actions, due to compliance with, accountability for and regulation of interests that exceed corporate boundaries (Christensen et al., 2015).

It is in this context that, since organizations generate impacts on workers, the environment and the community in which they are embedded, as well as on their shareholders, it is possible to say that, over time, companies have received increasing attention from society. In this sense, the support of stakeholder theory is that, due to the importance of companies and their impacts on society, they must be accountable to many more sectors of society than their shareholders alone.

Following this line, Muritiba \& Muritiba (2015) propose a universal model of CG that has four common dimensions and that can be adapted to different sizes, sectors, capital structures and types of organization. In the universal CG model, companies should consider stakeholders and responsibility for their social and environmental demands. Thus, the four CG dimensions proposed by the authors are property; team of senior executives; board of directors and other representatives; stakeholders and socio-environmental responsibility.

It should be noted that the concept of $C G$ is not limited to companies that are listed on the stock exchange, but is valid for all companies seeking a relationship of transparency and trust with stakeholders (Fung, 2014). Therefore, CG can be observed in organizations of various branches and sizes, from small companies to multinationals, as well as in public and cooperative organizations (Muritiba \& Muritiba, 2015).

Since CG is applicable to all types and sizes of organization, CG principles and codes of practice can also be applied in any organization. However, each company has its characteristic size, life stage, share structure, strategy and so on. In this context, there is no single set of rigid rules to be followed by all organizations (Abdallah \& Ismail, 2017). In this sense, IBGC (2015) reinforces the importance of the basic principles of good CG, since they support the foundations and conduct of the Code of Best Corporate Governance Practices, which apply to any type of organization, regardless of size, legal nature or type of control.

The code is a set of "best practice" recommendations for the behavior and structure of a company's board of directors to compensate for deficiencies in the country's CG system, with a view to protecting shareholder rights (Aguilera \& Cuervo-Cazurra, 2009).

The legitimacy that acceptance of the normative content of a code provides, as well as the efficiency of the practices prescribed in a code of good governance, are reasons that seem to explain the diffusion of codes of good governance around the world (Aguilera \& Cuervo-Cazurra, 2009; Rodriguez-Fernandez, 2016). Voluntary best practice codes, despite being criticized for limiting their ability to enable the evolution of organizations' governance, seem to contribute to improving CG performance in countries that have adopted them, despite the need for further improvements (Aguilera \& Cuervo-Cazurra, 2009).

In this sense, it can be highlighted that it is through CG practices that an organization can show credibility, attract capital and differentiate itself in the market. According to Schmidt \& Fahlenbrach (2017), good CG practices increase management efficiency, lower the cost of capital, bring new investment and provide business growth, with more rigorous controls and better ethical standards that increase tax revenue.

The main document issued by the IBGC - the Code of Best Corporate Governance Practices - has recommendations for good CG practices, with the aim of collaborating for the evolution of corporate governance in organizations operating in 
Brazil. These recommendations result from the IBGC's analysis and study of national and international, legal, regulatory, academic and practical approaches that address CG issues, as well as the results of the experiences and opinions of governmental bodies, the market, professionals and individuals with competence in CG and from international entities (IBGC, 2015).

The basic principles of $C G$ are guidelines for good management practices that normalize the relationships between ownership and managers, and between the organization and its stakeholders and society, as well as among company management (CVM, 2012; Black et al., 2015), to improve CG in companies (Muritiba \& Muritiba, 2015).

In this context, the principles developed by IBGC (2015, p. 20) are:

- Disclosure: Consists of the desire to make available to interested parties information that is of interest to them and not just that imposed by laws or regulations;

- Fairness: It is characterized by the fair and isonomic treatment of all partners and other stakeholders, taking into account their rights, duties, needs, interests and expectations;

- Accountability: Governance agents must be accountable for their actions in a clear, concise, understandable and timely manner, fully assuming the consequences of their acts and omissions and acting diligently and responsibly in their roles;

- Compliance: Governance agents must ensure the economic and financial viability of organizations, reduce the negative externalities of their business and operations and increase the positive ones, considering in their business model the various capitals (financial, manufactured, intellectual, human, social, environmental, reputational etc.) in the short, medium and long term.

The CG principles developed by the IBGC, more specifically the principles of transparency - a desire to provide information beyond that required by law - and accountability - to be accountable to society about the performance of agents and the organization, including corporate responsibility - ensure sustainability by incorporating social issues and environmental aspects, making it possible to verify that sustainability issues are part of good practices in CG, and that they should be analyzed by organizations that wish to improve their management.

Thus, through the analysis of the universal CG principles of the IBGC, it is already possible to identify the connection of these principles with the issues of environmental sustainability. The elements of the IBGC Code of Best Corporate Governance Practices, deployed from its universal principles, will be further analyzed and related to the ISO 14001: 2014 standard in this study.

The concept of sustainability is based on the premise that any type of corporation, public or private, as well as individuals, has commitments to society, since the impacts of human and corporate activity on the environment are, increasingly, perceived by society. The term corporate sustainability is the one most used to define the function of companies in the face of sustainability, and means the search for the longevity of the organization from its economic viability, together with its harmonious existence with the environment and society (BM\&FBOVESPA, 2015).

Companies gain competitive advantages and generate greater value from strategic investments in sustainability, establishing better environmental and social results. In this way, for companies to improve their vision and business strategy, it is 
necessary to generate value from social and environmental considerations, which include their internal processes and their culture, and contribute to the improvement of relations with their stakeholders (Barrena Martínez et al., 2016). It is in this sense that environmental protection becomes part of the organizational objectives, and the environment is no longer considered as a cost, but as a possibility for profit, in a panorama of threats and opportunities for the company (Gareau, 2013).

In this context, Morgan et al. (2009) emphasize that the company's role in society is to generate wealth by linking to the preservation of natural resources, as these resources become increasingly scarce. And following this, Baumgartner \& Rauter (2017) define that the main characteristic of a company focused on sustainability is its commitment to resolve social and environmental impacts with activities that respect the environment, through the adaptation of its products, processes and organizational structures in view of the different actors in the conduct of its business.

For Barbieri (2011), the environmental concerns of entrepreneurs are influenced by three major groups of forces: government, society and the market. For that author, if there were no pressures from society or government measures, the environmental involvement of companies would not be increasing.

Castka \& Prajogo (2013) point out that consumers, in making decisions for the acquisition of goods and services, increasingly value certified organizations, with quality seals and market credibility, and especially those that are included in the logic of environmental preservation.

Therefore, organizations of all types and sizes, in the environmental suitability of their processes and products, invest to obtain competitive advantages in the domestic market, as well as in the international market. In this scenario, the investments made by organizations can be accomplished through the implementation of the environmental norm ISO 14001, the certification of which is recognized nationally and internationally. This standard is intended to improve the environment by means of systemic management of the activities of organizations.

The standards of the ISO 14000 series were developed by the International Organization for Standardization (ISO), an independent and nongovernmental organization, founded in 1947 and with 162 member countries. According to ISO (2014), in its handbook on ISO 14000 , this series of standards provides practical tools for organizations of all types to be able to manage their environmental responsibilities.

It is in this context that the Environmental Management System (EMS), according to NBR ISO 14001, can be a useful management tool for organizations to achieve their environmental objectives, with benefits to society and protection of the environment. Machado et al. (2013), in their research, show that NBR ISO 14001 certified companies demonstrated greater concern regarding environmental management, with programs, actions and control of the resources employed. Thus, these companies differentiate themselves in the market, providing environmental benefits for the whole society: "[...] it is possible to affirm that certification by the ISO 14001 standard interferes positively in the administration of organizations" (Machado et al., 2013, p. 50).

Gavronski et al. (2008) found internal and external benefits for organizations in ISO 14001 certification. This well-developed study indicated that perceived benefits can be divided into two main groups: internal and external. Internal benefits are related to financial performance and productivity. External benefits are the relationship with stakeholders and the competitive environment. 
In the research carried out by Gavronski et al. (2012), three groups of motivations for ISO 14001 certification were identified: companies with an internal focus, companies with an external focus and a group of companies with an integrated focus. Companies with an internal focus are characterized by their orientation in operations and internal resources. Those with an external focus face the pressures of institutions that regulate the social environment. Companies with an integrated focus put a high value on all perspectives of motivation, regardless of whether they are internal or external.

For Oliveira \& Serra (2010), the greatest benefit found in the adoption of the EMS, according to ISO 14001 , is a stimulus to the development of environmental actions, with a consequent reduction in unforeseen costs. Benefits were also found in relation to a reduction in the consumption of water, electricity, oil and so on, as well as a positive influence of the EMS on the other processes of the organization, the company's image, and greater ease of compliance with environmental legislation and with environmental requirements imposed by customers.

In this same research carried out by Oliveira \& Serra (2010) on difficulties in adopting the EMS according to ISO 14001, it can be affirmed that there was an increase in costs for the companies surveyed, such as the need to adapt the organizational structure, training, awareness programs, modernization of equipment and conducting audits. Other difficulties pointed out by organizations concern periodic changes in environmental legislation, which make it difficult to comply with the requirements of ISO 14001, as well as budgetary difficulties, the need to hire specialized services and the existence of few companies for waste disposal.

For Oliveira \& Serra (2010), the greatest benefit found in the adoption of the EMS, according to ISO 14001, is the stimulus to the development of environmental actions, with the consequent reduction in unforeseen costs.

Finally, according to ISO (Arimura et al., 2016) , ISO 14001 users reported that the standard helps to show compliance with statutory and regulatory requirements; involves and increases the engagement of leadership and employees; improves the reputation of the company and the confidence of stakeholders; achieves strategic business objectives, incorporating environmental issues in the management of companies; provides a competitive and financial advantage through greater efficiency and cost reduction; and encourages better environmental performance of suppliers by integrating them into the organization's business systems.

The following section presents the methodological procedures used in this study.

\section{Methodological procedures}

To meet the objectives of this study, qualitative research was carried out using the content analysis method.

Qualitative research is focused on studies that show the complexity of a problem and analyzes the relationships of variables to classify and analyze dynamic processes (Arenhart et al., 2013). The qualitative approach was concerned with comparing the requirements of ISO 14001 with the elements of the IBGC code, as well as interpretation of the quality of the data surveyed in the environmental reports issued by the certification body in 2015 .

As an instrument for content analysis, a documentary analysis was performed. For Sá-Silva et al. (2009), documentary research is characterized by the source of data collection being limited to documents, which can be written or not, integrating 
what are called primary sources. In addition to the analysis of the relationship between the requirements of ISO 14001 and the elements contained in the IBGC code, the environmental reports issued in 2015 were analyzed by the same certification from RINA Brasil, totaling 139 companies certified according to ISO 14001: 2004. The certified companies that were analyzed are of different sizes and types of activity.

Thus, a total of 177 environmental reports issued by RINA Brasil (which is a body of ship classification, certification, compliance, inspection and testing services) were evaluated. The number of reports is higher than the number of certified companies because the audits may be semi-annual in some cases.

Initially, the requirements related to the elements of the IBGC code were identified in the ISO 14001 standard. Next, the elements contained in the IBGC code related to environmental issues were identified. As a result of identifying the requirements and elements of these two documents, the requirements of the standard and the elements of the code were analyzed and related, so that it was possible to identify the synergies present between these documents.

A synthesis of the relationship between the two documents was made through categorical analysis, which is based on the fragmentation of text into categories. The categories of analysis are social function of organizations; stakeholders; ethical identity to achieve objectives; universality of good practices, showing compliance to achieve objectives; organizational policies; measurement and monitoring; legislative compliance; resource availability; identification and analysis; and control of operational activities, internal audits, communication and senior management.

The categories of analysis were identified by observing the similar content of the documents, with thematic analysis of their respective approaches. In this way, the categories were directed to the similarities of the information contained in the requirements of the standard and in the recommendations of the IBGC code, analyzing its informational value and the words, arguments and ideas expressed in it.

Subsequent to ascertaining the relationship between the requirements of the standard and the elements of the code, and categorization of the relationships found, the environmental audit reports according to ISO 14001 issued in 2015 by RINA Brasil were analyzed. Data collection on certified companies, such as size, field of activity, date of audit and locality, is possible through the computerized system of the certification body itself. This same system also provides nonconformity data, as well as a description of the objective evidence found for issuing nonconformities.

Based on the list of all organizations that underwent ISO 14001 audit in 2015, the electronic reports were filtered out from the computerized system, and their information was transferred to an Excel file for analysis. The sources of the survey data related to audit reports cannot be accessed, since they are private and therefore closed to researchers. Thus, the research was sent for revalidation by another auditor from the certification body itself, who analyzed and confirmed the results obtained in this investigation. The approach adopted made it possible to highlight the items that companies are finding difficult to meet and, consequently, that have the potential to interfere with good CG practices.

As a limitation of this study, it is considered that IBGC's Code of Best Corporate Governance Practices was related to the ISO 14001 standard only by referring to its environmental elements, and also to other management elements similar to those found in the standard. These elements are broad, and in the comparison it is understood that the organization meets the elements of the IBGC code referring only 
to environmental management. It is also emphasized that the comparative analyses performed have different levels of intensity; that is, some relationships are strong and objective, while others have a lower degree of relationship between them.

\section{Data analysis and discussion}

The two documents that were analyzed - NBR ISO 14001: 2004 and the IBGC Code of Best Corporate Governance Practices - deal with good management practices, the first related exclusively to environmental management, the second related to CG, which covers environmental issues, since organizations today also have a social function and concerns about the impacts of their decisions on stakeholders, society and the environment. Table 1 presents a synthesis of the comparison between the two documents, with each relationship found associated to a theoretical category.

Table 1. Synthesis of the relationship established between the ISO 14001 rules and the IBGC's Code of Best Corporate Governance Practices.

\begin{tabular}{|c|c|c|c|}
\hline $\begin{array}{l}\text { NBR ISO } 14001 \\
\text { Requirements }\end{array}$ & $\begin{array}{l}\text { IBGC Code } \\
\text { Elements }\end{array}$ & Synthesis of Common Elements & $\begin{array}{l}\text { Theoretical } \\
\text { Category }\end{array}$ \\
\hline Introduction & Premises & $\begin{array}{l}\text { Insertion of the environmental } \\
\text { approach into organizations' activities. }\end{array}$ & $\begin{array}{l}\text { Social function of } \\
\text { organizations }\end{array}$ \\
\hline Introduction; 1.c & $\begin{array}{l}\text { Premises; } \\
3.4 ; 3.4 . a \text {. }\end{array}$ & $\begin{array}{l}\text { Ensure and show all stakeholders that } \\
\text { the company has adequate } \\
\text { management systems. }\end{array}$ & Stakeholders \\
\hline Introduction & $\begin{array}{l}\text { Premises } \\
\text { (organization } \\
\text { identification } \\
\text { and ethical } \\
\text { deliberation) }\end{array}$ & $\begin{array}{l}\text { Integrated management systems, } \\
\text { supported by an ethical identity, to } \\
\text { achieve their environmental and } \\
\text { economic objectives. }\end{array}$ & $\begin{array}{l}\text { Ethical identity to } \\
\text { achieve objectives }\end{array}$ \\
\hline Introduction; 1.c & $\begin{array}{l}\text { Premises } \\
\text { (code use) }\end{array}$ & $\begin{array}{l}\text { The universality of the rule/good practices } \\
\text { adoption by any type of organization. }\end{array}$ & $\begin{array}{l}\text { Good practice } \\
\text { Universality }\end{array}$ \\
\hline Introduction & Principles of CG & $\begin{array}{l}\text { To show the stakeholders the } \\
\text { adequacy of the practices adopted by } \\
\text { the organization, helping organizations } \\
\text { to achieve their environmental and } \\
\text { economic objectives, ensuring their } \\
\text { economic and financial viability. }\end{array}$ & $\begin{array}{l}\text { Show compliance } \\
\text { to achieve goals }\end{array}$ \\
\hline 4.2 & $\begin{array}{l}\text { 2.1.xii; 2.1.xiii; } \\
\quad 4.5 ; 4.5 . b\end{array}$ & $\begin{array}{l}\text { The organization should adopt specific } \\
\text { policies to establish acceptable limits for } \\
\text { its exposure to risks, ensure that top } \\
\text { management has knowledge and control } \\
\text { of the risks involved in the processes } \\
\text { and that they are positioned within } \\
\text { acceptable limits, and ensure that these } \\
\text { topics are linked to strategies. }\end{array}$ & $\begin{array}{l}\text { Organizational } \\
\text { policies }\end{array}$ \\
\hline 4.3.3; 4.5 .1 & $\begin{array}{l}\text { 2.1.c; } 2.11 . a . i ; \\
\text { 4.5.g; 4.5.h; } \\
\text { 5.10.d }\end{array}$ & $\begin{array}{l}\text { The organization's management } \\
\text { system must have measurable } \\
\text { objectives and targets, which enable } \\
\text { monitoring and the necessary } \\
\text { parameters for managers' decisions. }\end{array}$ & $\begin{array}{l}\text { Measurement and } \\
\text { monitoring }\end{array}$ \\
\hline $\begin{array}{c}\text { 4.3.2; 4.5.2; } \\
4.5 .2 .1 ; 4.5 .2 .2\end{array}$ & $\begin{array}{l}\text { 3.1; 4.1.2.a.vi; } \\
\text { 4.5; 4.5.c; 5.1.a; } \\
\text { 5.10.a; 5.10.b }\end{array}$ & $\begin{array}{l}\text { Expresses the organization's obligation } \\
\text { to comply with current laws and other } \\
\text { requirements to which it has } \\
\text { committed, with periodic evaluation. }\end{array}$ & Legal compliance \\
\hline
\end{tabular}


Table 1. Continued...

\begin{tabular}{|c|c|c|c|}
\hline $\begin{array}{l}\text { NBR ISO } 14001 \\
\text { Requirements }\end{array}$ & $\begin{array}{l}\text { IBGC Code } \\
\text { Elements }\end{array}$ & Synthesis of Common Elements & $\begin{array}{l}\text { Theoretical } \\
\text { Category }\end{array}$ \\
\hline 4.4 .1 & 3.1.a & $\begin{array}{l}\text { The organization has the responsibility } \\
\text { to make available the necessary } \\
\text { resources for the execution of actions } \\
\text { to ensure the adequacy of the systems. }\end{array}$ & $\begin{array}{l}\text { Provision of } \\
\text { resources }\end{array}$ \\
\hline $4.3 .1 ; 4.4 .7$ & $\begin{array}{l}\text { 2.1.a; 4.5.e } \\
\text { 4.1.2.a.iii; }\end{array}$ & $\begin{array}{l}\text { The organization should identify, } \\
\text { analyze and classify the risks involved } \\
\text { in its operation. }\end{array}$ & $\begin{array}{l}\text { Risks identification } \\
\text { and analysis }\end{array}$ \\
\hline 4.4 .6 & $2.1 . a ; 3.1$ & $\begin{array}{l}\text { The organization should identify and } \\
\text { plan operations that are associated } \\
\text { with significant environmental aspects } \\
\text { (impacts arising from its activities, } \\
\text { products and services in society and its } \\
\text { stakeholders) in accordance with its } \\
\text { environmental policy, objectives and } \\
\text { targets. }\end{array}$ & $\begin{array}{l}\text { Control of } \\
\text { operational } \\
\text { activities }\end{array}$ \\
\hline 4.5 .5 & 4.4 & $\begin{array}{l}\text { Indicates the need to perform internal } \\
\text { audits to monitor, maintain and adapt } \\
\text { operating systems. }\end{array}$ & Internal audits \\
\hline 4.4 .3 & 5.2; 5.2.a; 5.2.b & $\begin{array}{l}\text { The organization must have a } \\
\text { communication channel that allows the } \\
\text { interested parties to interact with it. }\end{array}$ & Communication \\
\hline 4.6 & 3.1 & $\begin{array}{l}\text { Top management is the body } \\
\text { responsible for the management of the } \\
\text { organization and must ensure that it is } \\
\text { acting in an appropriate manner. }\end{array}$ & Top management \\
\hline
\end{tabular}

Source: Prepared by the authors. Note: It should be noted that the items referring to NBR ISO 14001 are limited to the environmental approach, while the good practices of CG can also cover other perspectives besides the environmental one.

In the IBGC code, all the elements related to environmental topics were selected, and later management elements similar to those required by ISO 14001 were incorporated. It is important to note that some elements of the IBGC code that are related to the requirements of NBR ISO 14001 are broad; that is, they do not address only environmental issues. These are broad elements that can be related to other organizational management topics, and which were related since there is a similarity to the environmental management present in the ISO 14001 rules. Therefore, in this regard, the company attends to the elements of the IBGC code referring only to environmental management.

It can be observed that elements of the IBGC code are related to the auditable requirements of ISO 14001, section 4 (requirements 4.1 to 4.6 ); that is, the elements have technical correspondence to the requirements and therefore there are indications that the rules and the code can be used together for organizations that are already operating following one of these documents (rules or code), and wish to operate following both documents (rules and code).

In addition to the elements of the code that can be related to the auditable requirements of the rules, other elements of the code were related to the requirements of NBR ISO 14001, since it was possible to identify relationships between these elements of the IBGC code and the non-auditable requirements of the rules, showing similarities between both documents.

In the relationships identified it was possible to observe that almost all the requirements of ISO 14001 are related to the IBGC code. Of all the auditable requirements, which are the requirements of section 4 , requirements $4.2,4.3 .1,4.3 .2$, 
4.3.3, 4.4.1, 4.4.3, 4.4.6, 4.4.7, 4.5.1, 4.5.2, 4.5.5 and 4.6 were related. All the elements related to the environmental topic presented in the IBGC code were related, as well as management elements similar to ISO 14001. Therefore, it is possible to show that an organization that has an EMS according to NBR ISO 14001, implemented and maintained, complies with the environmental elements of the IBGC Code of Best Corporate Governance Practices.

After the relationship between the requirements of the rules and the recommendations of the code, the theoretical categorization of topics was carried out. The category "social function of organizations" was thus developed, identifying that environmental aspects have become a growing concern in organizations, since social and environmental challenges are part of their context, affecting their strategy and value chain, with impacts on their reputation and their long-term economic value. The "stakeholders" category verified the importance of stakeholders for organizations, which should provide a high level of transparency of their information, so that they can show environmental compliance to their stakeholders. The sphere of "ethical identity to achieve objectives" refers to the decision-making process in organizations, in which the identity of the organization must be considered, as well as the impacts of its actions on stakeholders, society in general and the environment, aiming at the common good to reach its environmental and economic objectives. The "universal good practice" group is about adopting the IBGC standard and principles, which apply to any type of organization, regardless of size, legal nature or type of control. The sphere of "show compliance to achieve objectives" refers to exhibiting environmental compliance to stakeholders, in order to demonstrate transparency and accountability to society, ensuring the economic and financial viability of the organization in order to achieve its objectives in terms of environmental and economic impacts. For the category of "organizational policies", it was observed that organizations should define specific policies to establish acceptable limits, to expose the organization to risks and to ensure that the theme of sustainability is in their strategic choices. The scope of "measurement and monitoring" is for organizations to define performance objectives and targets, which in this case include environmental aspects, and to regularly monitor and measure the main features of their operations, which should be in line with their principles and values. Regarding the "legal compliance" aspect, the organization must identify, comply with and evaluate compliance with environmental legislation. For the "provision of resources" category, the organization should make available, plan, organize and control resources to generate value in a responsible way for itself and its stakeholders. In the area of "risk identification and analysis", the organization should identify environmental risks (environmental aspects and impacts), be able to assess the probability of their occurrence, identify potential emergency situations and potential accidents, and implement measures for prevention or mitigation of the main risks to which it is subject. The category of "control of operational activities" determines that the organization should identify and plan its operations, to ensure that they are performed under specified conditions, so that it fulfills its purpose and social function. The "internal audits" area determines that the organization must carry out internal audits in planned periods and that such audits must be aligned with its strategy and be based on a risk matrix. For "communication", the organization must have a channel of reporting and internal communication with interested parties. The "top management" category determines that the board is the body responsible for managing the organization, and that its main objective is to make the organization 
fulfill its purpose and its social function. Top management should analyze organizational results, monitor performance and goals, observe stakeholder communication, analyze the organization's environmental performance, as well as other activities.

It is in this context that the development of the trend of the social function of organizations and their concerns about the impacts on stakeholders, society and the environment are linked to a learning process that leads them to evaluate their priorities in different phases of the business. Barbieri (2011) points out that the environmental concerns of entrepreneurs are influenced by three major groups of forces: government, society and the market, since if there were not the pressures of society and government measures, the environmental involvement of companies would not be growing.

For the G-20 and OECD (2015), in a globalized economy with international investments, good governance and corporate sustainability practices incorporate ethical, social and environmental issues and become increasingly important, especially in access to national and international funding, as well as attracting foreign capital.

It is in this context that the EMS, according to NBR ISO 14001, can be a useful management tool to help organizations achieve their environmental objectives, with benefits to society and protection of the environment. The results of Machado et al.'s (2013) research demonstrate that NBR ISO 14001-certified companies showed greater concerns regarding environmental management, with programs, actions and control of the resources employed. Therefore, these companies differentiate themselves in the market, enabling environmental benefits for the whole society.

According to NBR ISO 14001 (ISO, 2004), the proof of successful implementation of this standard can assure stakeholders that the organization has an appropriate environmental management system in place.

In this way, the application of the ISO 14001 rules results in improvement of the organization's relations with the environment, with benefits to society and transparency of information. This potential condition meets the demands of disclosure, accountability and corporate responsibility (compliance) present in the basic principles of CG, as well as the specific elements of the IBGC code, related in this study, which reveal the connection between environmental sustainability and corporate governance. It is worth noting the position of Aguilera \& Cuervo-Cazurra (2009), for whom good governance acts as an element of organizational improvement, as well as that of Machado et al. (2013), which indicates the positive effect of NBR ISO 14001 certification on companies.

Regarding the analysis of the nonconformities found in the certification body audit reports, first the characteristics of the companies that were part of the sample surveyed were analyzed.

It can be verified that the size of the companies in the sample varies. There were $38(27 \%)$ large companies, $35(25 \%)$ medium-sized companies, 54 (39\%) small companies and $12(9 \%)$ micro-enterprises.

The majority of the companies surveyed are in the industrial sector, at $67 \%$ of the total sample, with services and commerce accounting for $29 \%$ and $4 \%$, respectively.

With regard to the number of companies by economic activity, it was observed that the sample of organizations is varied in their economic activities, but predominantly in the activities of basic metals and metallic products, at 33 companies (24\%); then rubber and plastic products at 16 companies $(12 \%)$; followed by 
construction, with a total of 14 companies (10\%); then transport, warehousing and associated services, with 13 companies (9\%); and finally those classified as other services (administrative services in general), at 10 companies surveyed $(7 \%)$.

The diversity of companies with regard to financial size and industry contributes to Fung's position (2014), which establishes that CG can be incorporated by any type of company, with the aim of establishing a relationship of transparency and trust with the parties concerned. Regarding the environmental issue, we highlight Barbieri's (2011) approach that interprets the adequacy of the implementation of NBR ISO 14001 by any company that wishes to treat and prevent environmental problems resulting from its actions.

Once the sample was characterized, the nonconformities in the audit reports were analyzed, as can be seen in Table 2 .

Table 2. Total of nonconformities (NC) issued in the reports and total of companies that received nonconformities to the requirements of NBR ISO 14001.

\begin{tabular}{llcccc}
\hline \multirow{2}{*}{ Requirement } & \multicolumn{2}{c}{$\begin{array}{c}\text { Total NC issued } \\
\text { per requirement }\end{array}$} & $\begin{array}{c}\text { Total companies } \\
\text { with NC per } \\
\text { requirement }\end{array}$ \\
\cline { 3 - 6 } & & No. & $\%$ & No. & $\%$ \\
\hline 4.1 & General requirements & 2 & $2.2 \%$ & 2 & $2.7 \%$ \\
\hline 4.2 & Environmental police & 1 & $1.1 \%$ & 1 & $1.4 \%$ \\
\hline 4.3 .1 & Environmental aspects & 3 & $3.3 \%$ & 3 & $4.1 \%$ \\
\hline 4.3 .2 & Legal and other requirements & 15 & $16.7 \%$ & 12 & $16.4 \%$ \\
\hline 4.3 .3 & Objectives, targets and program(s) & 1 & $1.1 \%$ & 1 & $1.4 \%$ \\
\hline 4.4 .1 & Resources, roles, responsibility and authority & 1 & $1.1 \%$ & 1 & $1.4 \%$ \\
\hline 4.4 .2 & Competence, training and awareness & 2 & $2.2 \%$ & 2 & $2.7 \%$ \\
\hline 4.4 .5 & Control of documents & 2 & $2.2 \%$ & 1 & $1.4 \%$ \\
\hline 4.4 .6 & Operational control & 23 & $25.6 \%$ & 18 & $24.7 \%$ \\
\hline 4.4 .7 & Emergency preparedness and response & 19 & $21.1 \%$ & 16 & $21.9 \%$ \\
\hline 4.5 .1 & Monitoring and measurement & 3 & $3.3 \%$ & 3 & $4.1 \%$ \\
\hline 4.5 .2 & Evaluation of compliance & 11 & $12.2 \%$ & 7 & $9.6 \%$ \\
\hline 4.5 .3 & Nonconformity, corrective action and preventive & 3 & $3.3 \%$ & 3 & $4.1 \%$ \\
\hline action & 2 & $2.2 \%$ & 1 & $1.4 \%$ \\
\hline 4.5 .4 & Control of records & 1 & $1.1 \%$ & 1 & $1.4 \%$ \\
\hline 4.5 .5 & Internal audit & 1 & $1.1 \%$ & 1 & $1.4 \%$ \\
\hline 4.6 & Management review & & & & \\
\hline
\end{tabular}

Source: Research data.

It was identified that, for both the total number of nonconformities found in the reports and the number of companies that received nonconformities per requirement, the requirement "4.4.6 - Operational control" was the one that most had nonconformities issued. The second requirement by nonconformities issued was "4.4.7 - Emergency preparedness and response". The third and fourth were, respectively, "4.3.2 - Legal and other requirements" and "4.5.2 - Evaluation of compliance". As noted in Table 2, both requirements 4.3 .2 and 4.5 .2 refer to compliance with legal requirements, while requirement 4.3 .2 refers to the identification of and access to legal requirements and the determination of how these apply in aspects of the organization, while requirement 4.5 .2 refers to the periodic assessment of compliance with legal and other requirements. Since both 
requirements refer to compliance and assessment of legal requirements, if the total nonconformities per report and total number of companies that have nonconformities to requirements are added together, requirements for compliance with legal requirements becomes the issue with the highest number of nonconformities issued.

The data obtained indicate that companies have a focus on meeting internal and external requirements, a condition that meets the perspective of Gavronski et al. (2012), and that they have deficiencies in both. In internal questions, the items with the highest occurrence of nonconformities were "operational control" and "emergency preparedness and response". The greater occurrence of nonconformities in these items is in line with Oliveira \& Serra's (2010) approach, which indicates the need to adapt the organizational structure, to conduct training and to develop awareness programs as barriers to implementation and maintenance of the EMS. In the fulfillment of external requirements, the items "legal and other requirements" and "evaluation of compliance" were identified as having the highest volume of occurrences of nonconformities. These items are related to legal and other aspects, and in this context result from external demands to the company. This performance is also in line with Oliveira \& Serra's (2010) approach, which indicates the difficulty for companies in adapting to periodic changes in environmental legislation, and in addition, as Gavronski et al. (2008) point out, in evolving the relationship with external agents.

The requirements for which more nonconformities were pointed out, as reported in Table 2, were positively related to the IBGC code. Requirement 4.4 .6 of NBR ISO 14001 relates positively to elements 2.1.a and 3.1 of the IBGC code, since both deal with the planning and implementation of all processes related to the operation of organizations and with compliance with policies and goals, and are in accordance with the organization's purpose and social function, since it is necessary to consider the impact of its activities, products and services on society and stakeholders. The code determines this responsibility of the board of directors, while the rules refer to the responsibility of the organization and clearly states that operations must be identified and planned and must be associated with significant environmental aspects, which in the code is implied in the identification and planning of the environmental aspects of operations, as well as aspects considered as the function/social object of the organization.

Therefore, organizations are having difficulty attending to the elements of controlling the impact of their activities on society and the environment, required in the code, which demands that the organization fulfills its objective and its social function according to its policies, principles and values (IBGC, 2015, p.40):

[...] the board must exercise its attributions considering the social object of the organization, its long-term viability and the impacts arising from its activities, products and services on society and its stakeholders (externalities). (...) The board is the body responsible for the management of the organization, whose main objective is to make the organization fulfill its purpose and its social function. (...) This body is responsible for the preparation and implementation of all operational and financial processes, including those related to risk management and communication with the market and other stakeholders.

The identification of a high volume of nonconformities related to operational control is in line with Barbieri's approach (2011), which points to environmental management as a set of administrative and operational activities. Thus, it is possible 
to interpret that organizations that have a high volume of processes involved in different levels of complexity present the possibility of deviations from established standards.

The third and fourth requirements in which more nonconformities were pointed out are 4.3.2 and 4.5.2. Both refer to compliance with legal requirements, while requirement 4.3.2 refers to identification and access to legal requirements. The number of nonconformities in these requirements were added together, since both requirements relate to the fulfillment and evaluation of legal requirements, and for both the total number of nonconformities issued in the reports and the total number of companies that received notices of noncompliance with these requirements, the issue of legal aspects was the element in which more nonconformities were issued. The IBGC code at various times indicates the need for compliance with legislation, according to elements 3.1, 4.1.2.a.vi, 4.5, 4.5.c, 5.1.a, 5.10.a and 5.10.b. It requires that "the organization be in full compliance with the legal provisions and other internal policies to which it is subject: (IBGC, 2015, p. 69). Therefore, it is important to emphasize that the item with which companies are most nonconforming, according to environmental audit reports, is the service and evaluation of environmental legislation.

Thus, it was verified that compliance with environmental legislation is the item with which companies are having most difficulty complying, thus being a potential impediment to their overall compliance with the of IBGC code (IBGC, 2015, p. 91):

Governance agents have a responsibility to ensure compliance with laws and regulations, and external and internal standards must be guaranteed by a process of compliance monitoring of all activities of the organization.

The results of the research regarding the nonconformities found in the audit reports confirm the results found by Oliveira \& Serra (2010), which point to one of the difficulties of environmental management being periodic changes in environmental legislation, which make it difficult to comply with the requirements of NBR ISO 14001.

It is in this sense that certification according to NBR ISO 14001 helps organizations to show compliance with environmental legislation. ISO (Arimura et al., 2016) reports that users of the standard confirm that it helps to show compliance with statutory and regulatory requirements.

Compliance with legislation and behavioral rules is pointed out by Zagorchev \& Gao (2015) as an important attribution of companies that practice CG. In this sense, Rodriguez-Fernandez (2016) points out that acceptance of the normative content of the codes is potentially one of the factors that allows the diffusion of codes of good governance around the world.

In this context of the relationship between the rule and the code, the literature presents benefits both in the implementation of management systems according to NBR ISO 14001 and in the adoption of the IBGC code. For Oliveira \& Serra (2010), the greatest benefit found in the adoption of the EMS, according to NBR ISO 14001, is the stimulus to the development of environmental actions, with the consequent reduction of unforeseen costs. They also indicate benefits in relation to the reduction of consumption of water, electricity, oil and so on, as well as the positive influence of the EMS in the other processes of the organization and on the company's image. Other benefits have also been found to be protection of employee safety; awareness of social issues; better operational control; greater ease of compliance with environmental legislation; improvement in meeting environmental requirements 
imposed by large customers; better use of facilities and equipment; and better preventive maintenance of equipment.

According to ISO (Arimura et al., 2016), NBR ISO 14001 users reported that the standard helps to show compliance with statutory and regulatory requirements; involves and increases the engagement of leadership and employees; improves the reputation of the company and the trust of the stakeholders; achieves strategic business objectives, incorporating environmental issues in business management; provides a competitive and financial advantage through greater efficiency and cost reduction; and encourages better environmental performance from suppliers by integrating them into the organization's business systems.

In this sense, Castka \& Prajogo (2013) point out that consumers, in making decisions about the acquisition of goods and services, increasingly value certified organizations, with quality seals, credibility in the market and, especially, those that are presented within the logic of environmental preservation.

As for the CG best practice codes, Schmidt \& Fahlenbrach (2017) point out that it is through good CG practices that an organization can show credibility, attract capital and differentiate itself in the market.

Benites \& Polo (2013) point out that governance and corporate sustainability are important issues in a world in which the expectations of society regarding companies' adoption of good practices are increasing.

In the study by Seidl et al. (2013), it was found that the market responds positively to notices of compliance with the code of good practices. Finally, Klettner et al. (2014) define that CG challenge for sustainability as increasingly urgent. The starting point is the fact that corporations and governments are now confronted with the expectations of a society focused on social and environmental risks and negative impacts associated with economic development. Governance systems need to be redesigned so that they can assist in transforming economic development to bring it into line with sustainability principles and thus promote social and environmental justice. Firms are the central unit of economic development and governance systems seem to be fundamental to transforming corporate behavior in line with sustainability principles.

\section{Final considerations}

The research analyzed the adherence of the ISO 14001 standard to the IBGC's Code of Good Corporate Governance Practices. In research carried out on the standard, a set of requirements was identified in line with the IBGC code and audited by the EMS. In addition, evidence was provided that some elements of the introduction and chapter 1 of the standard are similar to the IBGC code.

In this study, 34 items were identified in the IBGC code that relate to the environmental issues present in the ISO 14001 standard. In the EMS standard, 14 items with similarity to the IBGC code were found.

In this sense, a positive relationship was observed between the requirements of the NBR ISO 14001 standard and the elements contained in the IBGC code. It is understood as a positive relation in terms of the elements/requirements that have technical correspondence between them and, therefore, it is possible to show that the norm and the code can be used jointly for organizations that already are operating following one of these documents (norm or code), and wish to adopt both (standard and code). It is important to note that some elements of the IBGC code that relate to 
the requirements of the ISO 14001 standard are broad; that is, they do not address only environmental issues.

By means of the relationship found, it can be observed that all the elements related to environmental management handled in the IBGC code can be met through audits according to ISO 14001. In the analysis performed on the 139 companies certified according to ISO 14001, making a total of 177 investigated reports, it was recorded that the companies received a total of 90 nonconformities during 2015.

The research on the audit reports of the independent certification body concluded that organizations, regardless of size or economic activity, received a greater number of nonconformities in requirements related to identification and determination of legal requirements and evaluation of compliance with legal requirements applicable to the aspects of environmental impacts. Therefore, companies are having difficulty attending to and evaluating environmental legislation, which, potentially, can prevent their compliance as demanded by the IBGC code. The code requires that "[...] the organization be in full compliance with the legal provisions and other internal policies to which it is subject" (IBGC, 2015, p. 69).

Another requirement that organizations have difficulty meeting is operational control, which refers to the control of operational activities that are associated with significant environmental aspects, according to their policy, objectives and goals. This requirement was positively related to elements in the IBGC code which recommend that the organization control the impact of activities on society and stakeholders, fulfilling its purpose and social function according to its policies. Therefore, organizations, in their operating activities, can potentially impact society and the environment through a lack of operational control of their activities, in contravention of the recommendations in the IBGC code and ISO 14001.

Therefore, it was shown that an organization that has an EMS according to ISO 14001, which is implemented and maintained, complies with the environmental elements of the IBGC code. In addition, certification according to ISO 14001, by an external and independent body, with the issuance of reports and a certificate of conformity, serves as an instrument to show interested parties that the organization has an appropriate EMS in place.

In this way, the application of the ISO 14001 standard results in improvement of the organization's relations with the environment, with benefits to society and transparency of information. This potential condition meets the demands of disclosure, accountability and compliance present in the basic principles of CG, as well as the specific elements of the IBGC code, which were related in this study and reveal the connection between environmental sustainability and CG.

This research concluded that companies that choose to implement NBR ISO 14001 can, in complying with the requirements of this standard that deals with adequate environmental management, also attend to the elements of environmental sustainability of the IBGC Code of Good Corporate Governance Practices, and have economy in the application of resources and efforts. Thus, the more companies opt for the implementation of ISO 14001 and the code, the better their environmental management and, in this way, the impacts and risks to the environment will be minimized or solved, in accordance with the wishes of society, government and the market.

As a possibility for future studies, it would be feasible to update this research, relating NBR ISO 14001 in its new version from 2015 not only to the IBGC code but also other management system standards. The research used ISO 14001: 2004, because it was based on this version under which the audits that provided the research data were performed. 


\section{References}

Abdallah, A. A., \& Ismail, A. K. (2017). Corporate governance practices, ownership structure, and corporate performance in the GCC countries. Journal of International Financial Markets, Institutions and Money, 46, 98-115. http://dx.doi.org/10.1016/j.intfin.2016.08.004.

Aguilera, R. V., \& Cuervo-Cazurra, A. (2009). Codes of good governance. Corporate Governance, 17(3), 376-387. http://dx.doi.org/10.1111/j.1467-8683.2009.00737.x.

Arenhart, L. E., Campigotto, L., Sehnem, S., \& Bernardy, R. J. (2013). A adoção de práticas sustentáveis e certificação ISO 14.001: um estudo de caso em um escritório de advocacia e consultoria jurídica. Revista de Gestão Ambiental e Sustentabilidade - GeAS, 2(2), 125159.

Arimura, T. H., Darnall, N., Ganguli, R., \& Katayama, H. (2016). The effect of ISO 14001 on environmental performance: resolving equivocal findings. Journal of Environmental Management, 166, 556-566. http://dx.doi.org/10.1016/j.jenvman.2015.10.032. PMid:26606323.

Associação Brasileira de Normas Técnicas - ABNT. (2004). NBR ISO 14001:2004 - Sistemas da gestão ambiental - requisitos com orientação para uso (2. ed.). Rio de Janeiro: ABNT.

Barbieri, J. C. (2011). Gestão ambiental empresarial: conceitos, modelos e instrumentos (3rd ed.). São Paulo: Ed. Saraiva.

Barrena Martínez, J., López Fernández, M., \& Romero Fernández, P. M. (2016). Corporate social responsibility: evolution through institutional and stakeholder perspectives. European Journal of Management and Business Economics, 25(1), 8-14. http://dx.doi.org/10.1016/j.redee.2015.11.002.

Baumgartner, R. J., \& Rauter, R. (2017). Strategic perspectives of corporate sustainability management to develop a sustainable organization. Journal of Cleaner Production, 140, 81-92. http://dx.doi.org/10.1016/j.jclepro.2016.04.146.

Benites, L. L. L., \& Polo, E. F. (2013). A sustentabilidade como ferramenta estratégica empresarial: GC e aplicação do triple bottom line na masisa. Revista Administração UFSM, 6, 827-841.

Black, B. S., Kim, W., Jang, H., \& Park, K.-S. (2015). How corporate governance affect firm value? Evidence on a self-dealing channel from a natural experiment in Korea. Journal of Banking \& Finance, 51, 131-150. http://dx.doi.org/10.1016/j.jbankfin.2014.08.020.

BM\&FBOVESPA. (2015). Novo valor: sustentabilidade nas empresas como começar, quem envolver e o que priorizar. São Paulo: BM\&FBOVESPA.

Castka, P., \& Prajogo, D. (2013). The effect of pressure from secondary stakeholders on the internalization of ISO 14001. Journal of Cleaner Production, 47, 245-252. http://dx.doi.org/10.1016/j.jclepro.2012.12.034.

Christensen, J., Kent, P., Routledge, J., \& Stewart, J. (2015). Do corporate governance recommendations improve the performance and accountability of small listed companies? Accounting and Finance, 55(1), 133-164. http://dx.doi.org/10.1111/acfi.12055.

Comissão de Valores Mobiliários - CVM. (2012). Recomendações da CVM sobre governança corporativa. Rio de Janeiro: CVM.

Fung, B. (2014). The demand and need for transparency and disclosure in corporate governance. Universal Journal of Management, 2(2), 72-80.

Gareau, B. (2013). From precaution to profit: contemporary challenges to environmental protection in the montreal protocol. New Haven, CT: Yale University Press. http://dx.doi.org/10.12987/yale/9780300175264.001.0001.

Gavronski, I., Ferrer, G., \& Paiva, E. L. (2008). ISO 14001 certification in Brazil: motivations and benefits. Journal of Cleaner Production, 16(1), 87-94.

http://dx.doi.org/10.1016/j.jclepro.2006.11.002. 
Gavronski, I., Paiva, E. L., Teixeira, R., \& Andrade, M. C. F. (2012). ISO 14001 certified plants in Brazil: taxonomy and practices. Journal of Cleaner Production, 39, 32-41. http://dx.doi.org/10.1016/j.jclepro.2012.08.025.

Harrison, J. S., \& Wicks, A. C. (2013). Stakeholder theory, value, and firm performance. Business Ethics Quarterly, 23(1), 97-124. http://dx.doi.org/10.5840/beq20132314.

Instituto Brasileiro de Governança Corporativa - IBGC. (2015). Código das melhores práticas de governança corporativa (5th ed.). Retrieved in 2016, April 5, from http://www.ibgc.org.br/inter.php?id=18180

International Organization for Standardization - ISO. (2014). The ISO survey of management system standard certifications: executive summary. Retrieved in 2016, April 5, from http://www.iso.org/iso/iso_survey_executive-summary.pdf?v2014

Klettner, A., Clarke, T., \& Boersma, M. (2014). The governance of corporate sustainability: empirical insights into the development, leadership and implementation of responsible business strategy. Journal of Business Ethics, 122(1), 145-165. http://dx.doi.org/10.1007/s10551-013-1750-y.

Machado, C., Jr., Mazzali, L., Souza, M. T. S., Furlaneto, C. J., \& Prearo, L. C. (2013). A gestão dos recursos naturais nas organizações certificadas pela norma NBR ISO 14001. Produção, 23(1), 41-51. http://dx.doi.org/10.1590/S0103-65132012005000005.

Morgan, G., Ryu, K., \& Mirvis, P. (2009). Leading corporate citizenship: governance, structure, systems. Corporate Governance: The International Journal of Business in Society, 9(1), 3949. http://dx.doi.org/10.1108/14720700910936047.

Muritiba, S. N., \& Muritiba, P. M. (2015). Governança corporativa conceitos básicos e modelo universal. São Paulo: Ed. Gepra.

Oliveira, O. J., \& Serra, J. R. (2010). Benefícios e dificuldades da gestão ambiental com base na ISO 14001 em empresas industriais de São Paul. Produção, 20(3), 429-438. http://dx.doi.org/10.1590/S0103-65132010005000013.

Organisation for Economic Co-operation and Development - OECD. (2015). G-20/OECD principles of corporate governance. Paris: OECD. Retrieved in 2017, April 23, from https://www.oecd.org/daf/ca/Corporate-Governance-Principles-ENG.pdf

Rodriguez-Fernandez, M. (2016). Social responsibility and financial performance: the role of good corporate governance. BRQ Business Research Quarterly, 19(2), 137-151. http://dx.doi.org/10.1016/j.brq.2015.08.001.

Sá-Silva, J. R., Almeida, C. D., \& Guindani, J. F. (2009). Pesquisa documental: pistas teóricas e metodológicas. Revista brasileira de História \& Ciências Sociais, 1(1), 1-15.

Schmidt, C., \& Fahlenbrach, R. (2017). Do exogenous changes in passive institutional ownership affect corporate governance and firm value? Journal of Financial Economics, 124(2), 285-306. http://dx.doi.org/10.1016/j.jfineco.2017.01.005.

Seidl, D., Sanderson, P., \& Roberts, J. (2013). Applying the 'comply-or-explain' principle: discursive legitimacy tactics with regard to codes of corporate governance. The Journal of Management and Governance, 17(3), 791-826. http://dx.doi.org/10.1007/s10997-011-9209-y.

Zagorchev, A., \& Gao, L. (2015). Corporate governance and performance of financial institutions. Journal of Economics and Business, 82, 17-41. http://dx.doi.org/10.1016/j.jeconbus.2015.04.004. 